\title{
Excellence Ethnic Characters in Strengthening the Country National Values Identity: An Experience of Indonesia
}

\author{
Carolina Lasambouw ${ }^{1, *}$ Ediana Sutjiredjeki ${ }^{2,}$ Neneng Nuryati ${ }^{3}$ \\ ${ }^{1,2,3}$ Politeknik Negeri Bandung, Indonesia \\ *Corresponding author. Email: carolina.magdalena@polban.ac.id
}

\begin{abstract}
Each country has specific values as the country's identity, which generally lay in the basic description of the country's historical background, socio-cultural conditions, and shared values and dreams. In Indonesia, the values of state identity are inside the Five Fundamental Principles known as Pancasila. As a multicultural country, the contribution of the excellent character of the ethnic groups in Indonesia must strengthen and enrich the values of national identity. However, the power of ethnicity to support the nation's collective values is rarely explored due to the fear of interethnic competition that can lead to feuds. Even the views that ethnicity is an obstacle to unity. This qualitative study focuses on identifying the excellent ethnic characters and the linking to support the values of the Five Fundamental Principles. Literature studies and interviews are used to obtain data and information on 13 tribes' excellence characters from purposively selected participants. The study found ten generic characters, namely: Religious, Honest, Courageous, Sincere, Faithful, Migrant, Collaborative, Firm, Resilient, Friendly. These characters represent the identity of the country's national values. Bearing in mind that a multicultural society has unique strengths in its superior character, the state needs to implement a strategy that will provide a platform for people to respect each other.
\end{abstract}

\section{Keywords: Character, Ethnic, National Identity.}

\section{INTRODUCTION}

Each country has specific values as the identity of that country. The concept of identity refers to feeling and consciousness of self-recognition. Then in social interactions, the development continues to the sense of belonging of groups as hetero-recognition [1]. Furthermore, the hetero-recognition reflects a country's values identity. Therefore, national identity is a person's identity or sense of belonging to one state or one nation $[2,3]$. It is the sense of a nation as a cohesive whole, as represented by distinctive traditions, culture, and language [4]. National identity may refer to the subjective feeling individual shares with a group of people about a nation, regardless of one's legal citizenship status [5 Ethnicity describes a joint identity and is based on the postulation that a collectivity has its roots in common descent, heritage, religion, culture, nationality, language and region [19]. Generally, the value of a country's national identity lay in the basic description of the country's historical background, sociocultural conditions, and shared values and dreams. They are the sources of the fundamental conception of the ideals of a nation-state. [6]. Nowadays, the determinant factors of national greatness are skills, industriousness, productivity and competitiveness and not the size of its population or the abundance of its natural resources. Thus, the real wealth of a nation is its people and their capacity to engender productivity, creativity and industriousness [20]. Globalization perspectives tend to perceive the nation as a transitional unit between traditional localism and planetary interdependence. From this perspective ethnicity is dismissed as a characteristic of 'simpler' 'pre-political' societies, or of marginal groups destined to assimilate into existing states [21].

Indonesia is known as a multicultural country. The contribution of the excellent character of the ethnic groups in Indonesia is needed to strengthen and enrich the values of national identity. The collaboration between Central Bureau of Statistic and Institute of South Asian Studies in 2010 formulated 633 ethnic groups obtained from 1340 tribes and sub-tribes in Indonesia. Thousands of islands in the Unitary State of the Republic of Indonesia are characteristics that this country is a country with a diversity of ethnicities and different cultural backgrounds.

In Indonesia, the values of state identity are inside the Five Fundamental Principles known as Pancasila. The values contained in the Five Fundamental Principles were "excavated" by Indonesia's founding fathers from people's lives. Based on history, the values of national 
identity in Indonesia have been agreed upon by the country's founding fathers [7].

In the past, the power of ethnicity to support the nation's collective values rarely explore. This condition is partly due to the fear of inter-ethnic competition that can lead to feuds. Many views say that ethnicity is an obstacle to unity and unity.[8]. However, this concern was not proven, first, from the empirical condition of Indonesia, which rarely experiences inter-ethnic wars. Second, the measurement of ethnic diversity in the 2010 population census indicates that the potential impact of inter-ethnic conflict in Indonesia tends to below. Based on the measurement value of ethnic diversity in Indonesia, the Ethnic Fractionalize Index (EFI) and the Ethnic Polarized Index (EPOI) show that the EFI is 0.81 and the EPOI is 0.50. [9]. Research findings regarding the prominent characters of 5 ethnic groups in Indonesia with the largest population [10] show that each ethnic group has its excellent character. Some characters are the same, while others are unique to the ethnic group.

Based on the population census undertaken in the year 2020, Indonesia has more than 270 million population. Among them, there is a population known as Generation-Z (27.94\%). This generation is currently at the age of 8-23 years, and Post Generation-Z (10.88\%) currently at the age of 7 years and below. This young generation population has become the target of character education hosted by schools. In comparison, the age of the Millennia Generation at the moment is 24-39. They have entered the workforce or become an entrepreneur. These two generations are targets of character education carried out by schools, given that this national identity is critical to continue and preserved. Especially in the future when technology is increasingly "eroding" identity through various services or facilities. Identity is the last bastion of understanding the future. Even identity is also essential to solve problems in contemporary life [12] [13].

This paper describes the research findings on the prominent characters of the 13 ethnic groups in Indonesia, which have the largest population. Furthermore, it is also explained about the relationship of excellent ethnic characters to strengthen national identity in the Five Fundamental Principles, which are the basis of the Indonesian state

\section{LITERATURE REVIEW}

\subsection{National Value Identity}

Each country has specific values that become the identity of that country. Generally, the value of a country's national identity lay in the basic description of the country. The fundamental conception of the state and the ideals of each nation-state have their characteristics arising from the historical setting, socio-cultural conditions, and the shared values and dreams of the nation concerned. (Latief, 2018). The concept of identity refers to feeling and a consciousness of a self. They remain themselves in the face of others and notwithstanding change. The formation of identity depends on intricate processes of self-recognition. (Nevola, 2011). Furthermore, in social interactions, personal identity develops into hetero-recognition, which forms collective identity. A collective identity reflects the sense of belonging, where groups are variable by nature, size, or other features. Collective identity has many faces, such as 1) A collective identity is cultural when a group's self-and hetero-identification lay on a series of elements. Usually recognize as cultural: language, literary and artistic tradition, habits, rules of social behavior, religion, historical memory, various beliefs, myths, rites, symbols. 2) In some cases, these identity elements are shared by a group within a delimited territory relating to its material, historical and symbolic features. These aspects become another factor giving shape and content to the collective identity. 3) Finally, a collective identity acquires its guise as a political identity based on a particular condition. (Nevola, 2011).

\subsection{Five Fundamental Principles}

In Indonesia, the values of state identity is package in the Five Fundamental Principles which known as Pancasila. The first principle is a belief in one supreme being. Understanding this principle is left as a general statement, broad enough to encompass various religions. The second principle declares as a commitment to just and civilized humanitarianism. It means a willingness to treat others, even foreigners, in a fair manner, free from suspicion, exploitation, and oppression.

Moreover, the third principle expresses a commitment to the unity of Indonesia. Especially bearing in mind that Indonesia is an archipelago with multicultural population. The fourth principle emphasizes the idea of a people governed by wise policies obtained through consultation and consensus. The fifth principle expresses a commitment to social justice for all the Indonesian people. (MOEC, 2016;).

As the basis of the state, the Five Fundamental Principles are the foundation and source of shaping and administering the state. They become the source of all sources of state law. This fundamental norm is the highest norm that underlies the unity of norm systems in an orderly society, including the state, which is unchanging (Attamimi in Osman and Alfian, 1993: 74).

\subsection{Ethnic Characters and National Value Identity}

The values included in the Five Fundamental Principles need to be applied in the social life of the Indonesian people because these values are collective. One of the characteristics of Indonesia as a nation-state is its vastness, breadth, and diversity. Realizing that the values included in the Five Fundamental Principles constitute the identity of the Indonesian people, the contribution of the excellent character of the 1340 ethnic groups in Indonesia, which grouped into 633 ethnic groups, is very potential to support the achievement of the country's ideals. A multicultural society that respects cultural differences create a society with the same views, souls and goals. (Pitoyo and Triwahyudi, 2017). 
Moreover, in this era of globalization, the noble values of the Five Fundamental Principles continue to experience degradation, especially among the younger generation or among students. Currently, the noble values of Pancasila are starting to fade. For example, the increasing indifference, the attitude of wanting to win alone, disloyalty to friends. The causes of the loss of these values are very diverse, including social disparities or social status, due to the selfish attitude of each individual, lack of understanding or cultivation of the values of social care, lack of tolerance, sympathy, and empathy. (Muhamadi and Hasanah, 2019). Another finding is the emergence of a contradictory condition between recognizing the ability of higher education graduates to master their field of expertise but not having a unique character. Asyanti, S (2012).

\section{MethodS}

The research uses a qualitative exploratory method. It starts with a literature review and deep study to gather initial information on the main customs and taboo matters that apply in each of the 13 (thirteen) largest ethnic groups in Indonesia, representing the 5 (five) largest islands in Indonesia. Then, a list of questions made to deliver interviews. Targeted respondents for interviews selected purposively in line with the research objectives. They are people who understand and understand the customs or taboos that the tribe/ethnicity strongly believes. Further, the researchers carried out interviews with 30 people representing the community from the relevant ethnic groups. The focus is on identifying the character stated as very important and very strong within the community. These characters may provide the identity of the excellent characters of the tribe and compile into a list of prominent characters. The data were processed and tabulated according to ethnicity. Then the finding described in details.

\section{RESULT AND DISCUSSION}

\subsection{Identifying Excellence Ethnic Characters}

Historically, the development of ethnicity in Indonesia is heterogeneous with high diversity [9]. Considering that the mobility of people between regions is getting higher in line with better and faster available modes of transportation, it may increase the recognition between ethnicities and cultural diversity which could lead to acculturation. Acculturation is the process of entering the influence of a foreign culture in a society, some selectively absorb few or many elements of the foreign culture, and some try to resist that influence [15].

Based on the 2010 CBP census in Indonesia, there were 1,340 ethnics which are classified into 633 major ethnic groups. Furthermore, it is a fact that the population among these ethnic groups is not evenly distributed. The fifteen (15) tribes with the largest population including the Javanese Tribe as the largest population $(95,217,022$ people), namely $40.05 \%$. Occupying the second position is the Sundanese with a population of $36,701,670$ people or $15.5 \%$.
Furthermore, other tribes have a proportion below five percent of Indonesia's population, namely the Batak Tribe with $8,466,969$ people or $3.58 \%$. The fourth rank is ethnic groups from Sulawesi apart from Bugis, Makassar, Gorontalo and Minahasa. In fifth place is the Madurese Tribe with a population of $7,179,356$ or $3.03 \%$. The sixth place is the Betawi Tribe with a population of $6,807,968$ or $2.88 \%$. The seventh position is the Minangkabau Tribe with a population of $6,462,713$ or 2,735 people. The eighth is the Bugis Tribe with a population of $6,359,700$ or $2.69 \%$. The ninth is the Malays with a population of 5,365,399 or $2.27 \%$. The tenth is the tribe from South Sumatra with a population of $5,119,581$ or $2.16 \%$. Furthermore, the eleventh rank is the tribe in Banten with a population of $4,657,784$ or $1.97 \%$. The twelfth ranks are the tribes originating from East Nusa Tenggara with a population of $4,184,923$ people or $1.77 \%$. The thirteenth rank is the Banjar Tribe with a population of $4,127,124$ or $1.74 \%$. The fourteenth are the ethnic groups from Aceh with a population of $4,091,451$ or $1.73 \%$. And in the fifteenth order is the Balinese Tribe with a population of $3,946,416$ or $1.67 \%$.

Each ethnic group has a different superior character. Passed down from generation to generation in various ways, including through teaching about local wisdom, the sacredness of cultural customs and taboo matters. The findings of the main characters of the Javanese tribe are shown in Table 1.

Table 1. Javanese Character

\begin{tabular}{|l|l|l|}
\hline No. & Mainland Javanese & Coastal Javanisese \\
\hline 1. & Simple lifestyles. & $\begin{array}{l}\text { Expressive and } \\
\text { Open. }\end{array}$ \\
\hline 2. & Unity in harmony. & Friendly and Kind. \\
\hline 3. & $\begin{array}{l}\text { Good at maintaining } \\
\text { ethics and language. }\end{array}$ & $\begin{array}{l}\text { Hardworking and } \\
\text { Simple manners. }\end{array}$ \\
\hline 4. & Upholding the Customs & Mutual Attitude. \\
\hline 5. & $\begin{array}{l}\text { Nrimo ing pandum } \\
\text { (Submission) }\end{array}$ & $\begin{array}{l}\text { Has a Strong Belief } \\
\text { and Customary } \\
\text { System. }\end{array}$ \\
\hline 6. & $\begin{array}{l}\text { Urip ora ngoyo (Life as } \\
\text { it is) }\end{array}$ & \\
\hline
\end{tabular}

Source: Results of data processing

It is also found that the happiness level of the majority of Javanese people is at a high level. The seven strengths of character that contribute most to happiness are tenacity, creativity, perspective, justice, vitality, curiosity, and forgiveness. Meanwhile, the five most prominent character strengths are gratitude, kindness, submission, justice, and integrity. Javanese ethnicity is also very well known for its leadership character. [16].

The Sundanese are known for their religious beliefs which are expressed through the words silih asih, silih asah, and silih asuh which means loving one another, sharpening oneself, maintaining and protecting each other. Therefore, the Sundanese are known to be sociable, like to work together, and friendly. Also, the 
desire to always be seen as good and helpful to others continues to be attached to the identity of the Sundanese people and has become an ethnic identity [17].

The Batak tribe has a complete cultural wealth in regulating life. "Dalihan Natolu" is one of the cultural treasures of the Toba Batak community. In particular, regulating the kinship system and patterns of relationships in everyday life with God, ancestors, close family, neighbors, relatives, and others. The superior character of the Batak tribe apart from having a "golden voice", is also a migrant who is tough and resilient, honest, consistent, never gives up, works hard, and works collaborative.

The Madurese social relationship system is very unique through the Tanean Lanjang settlement pattern. A traditional house equipped with a surau for congregational prayer. Religious leaders play a very important role. The character of the Madurese Tribe tends to be individual, prioritizing rational economic thinking such as simplicity, hard work, and frugality.

The Betawi Tribe has a character that tends to speak plainly, straightforwardly and honestly. And also known to be very religious. Pencak Silat makes the Betawi Tribe tough and confident, and used to defend the weak and oppressed.

The Minangkabau Tribe strongly hold on to their traditions and culture, even though they have extensive relations with foreigners since the colonial period. The most prominent character of the Minangkabau Tribe is that they like to migrate. The personal and social life of the Minangkabau Tribe is based on the philosophy of Bundo Kanduang. This philosophy taught the Minangkabau community to be able to win without fighting, or if the situation was urgent, retreat so that it would not be destroyed. If they are faced with the enemy, and they have more control over the battle, they are prohibited from finishing off the enemy, and are encouraged to give forgiveness, so that the enemy submits without leaving hatred. Maintaining life (survival) both for oneself and for others, including even enemies, is the main message of Bundo Kanduang. [18].

The Bugis Tribes live on the southern part of Sulawesi Island. The life of the Bugis tribe is filled with the principles and values of the customs and teachings of the Islamic religion. The Bugis Makassar Tribe is known as people who are loyal, solider and strong. Takunjunga 'building turu' Nakugunciri 'gulingku Kualleangna talaanga natolia, meaning: "I don't just go with the wind, and don't just turn my steering wheel. I'd rather sink than come back." That is, if a step has swung, abstain from receding - preferring to sink rather than returning empty handed. Strict discipline teaches children to become people who can quickly become independent or can manage their own lives.

The Malays Tribe are accustomed to living in groups which maintain good relations with other Malay communities. This is done by maintaining an attitude of solidarity. Fasafah "Adat actually adat" which is applied by the Malays means: "full is not abundant, contains nothing less, the great is raised, the old is respected, the little is loved, the sick is treated, the fool is taught, the right is given rights, the strong does not attack, those who are tall do not squeeze, those who are smart do not cheat, live accordingly, eat accordingly. Therefore, the Malay community thinks that life should be harmonious, including themselves, the whole country, and the environment.

The largest tribe in the Banten area is the Baduy Tribe. The Baduy Tribe is located in the Lebak area, Banten. Based on its geographical conditions, the Baduy Tribe is in an area that is very far from urban areas and far from the modern world. The Baduy community is divided into two parts, namely the Inner Baduy Tribe (Inner Kanekes) and the Outer Baduy Tribe (Outer Kanekes).

The general character of the Baduy Tribe is caring for the environment. The Baduy community is a community figure who always observes the mandate of their ancestors, especially in maintaining harmony and balance in the universe. In his view, the main task of being born into the world is to be ascetic. This means that it does not change and damage nature so that the balance of its functions and benefits is maintained for the welfare and harmony of human life. If that obligation is not fulfilled then they will be labeled as sinful creatures. In addition, the Baduy Tribe likes to work together (Rereongan); law abiding; democratic; honest (For the Baduy community, honesty is self-respect. That is, someone is appreciated, respected, and honored by the community because of his honesty. A dishonest person has no self-respect). Other characters of the Baduy Tribe are independent and hardworking.

The Banjar Tribe, which implements a patrimonial culture, inhabits the area of South Kalimantan. The tribe is a mixture of several ethnicities, the most dominant being the Dayak Bukit ethnicity as the original inhabitant of South Kalimantan. The Banjar ethnic group is an ethnic group that is unique because it has a distinctive characteristic, namely the ethnic customs of the Banjar, which are often called "madam" or moving from one area to another. This transfer can be done more than once, with the aim of finding a more fertile area for developing agriculture and seeking inner and outer peace of life. The superior characters of the Banjar Tribe include outgoing, like to socialize, diligent in religion, like to trade, obey the rules, deliberation and kinship.

The Acehnese live in Aceh Province and have 13 sub-tribes, and each tribe has its own customs and language which are different from one another. Aceh is known as the "Serambi Mekkah" because it has very strong Islamic ideological values. Historically, most of the people of Aceh were migrants from various regions who later settled in Aceh. Including Indian, Arabic, Persian and Turkish descent. This is because of the marriage between the traders who entered Aceh land and 
the Acehnese. Among the newcomers, the oldest Acehnese are from the Mante Tribe of Malay.

The character of the Acehnese tribe is firm, ruleabiding, loyal, consistent, militant (this trait is expressed in the Acehnese idiom "meunyoe ka bak $\mathrm{u}$, han mungken like pineung." Reactive character (meaning as an attitude of awareness of self-esteem whose existence is at stake in the socio-cultural constellation. The Acehnese are very sensitive to the social situation around them.); Scientific (contained in the hadih maja stanza which reads: "Punca phon teelan beuna 'eleum'ee Hoho nyang tase keureuja tateum'ee." uneun 'ab bu Jaroe wie kawe eungkot (Right hand eat rice Left hand fishing), Optimistic (Acehnese think that every job that looks difficult and heavy should be tried and passed); The spirit of migrating (Duek di gampong gadoh lam awo Tajak meuranto mudah Bahagia)), which means living in a busy village, it is not clear than going abroad is easy to be happy); sportsmanship (Lam useuha bek deungki khianat Bek iri ate watee gob na nekmat) - meaning in trying not to be treacherous and not jealous if people get favors); and be patient in trying (Jeuneh raseuki wajeb tagagah Bah pih phon lousy tasaba Kareuna saba le that faidah Jeuet keu beure is it syupeu'at pih na) - it means that all sustenance must be sought, although it is difficult to be patient, because patience has many benefits so there are blessings for results).

The Balinese have the ability in dance, performing arts, and carving arts. Balinese culture holds a lot of potential for democratic values. The first layer is the ideas that conceptualize the most substantive matters in social life, followed by the more concrete layers, namely norms and laws. The empirical manifestation of democratic values can be seen when the special ceremony "pemarisuda karipubaya" which means the purification of the universe after the tragedy is believed to have polluted and disturbed the balance of nature in Bali. Balinese people can restrain themselves and not take acts of 'revenge' with violence, but instead take a spiritual approach that symbolically contains messages of peace, unity and tolerance that transcend boundaries of race, state, ethnicity, religion and have gained community empathy and sympathy local, national and world. The Balinese are also known to have the character of smiling, honesty, mutual tolerance, easy friendship, and obedience in various traditional ceremonies.

Table 2 Identification of Superior Characters of 13 Tribes with Largest Population in Indonesia

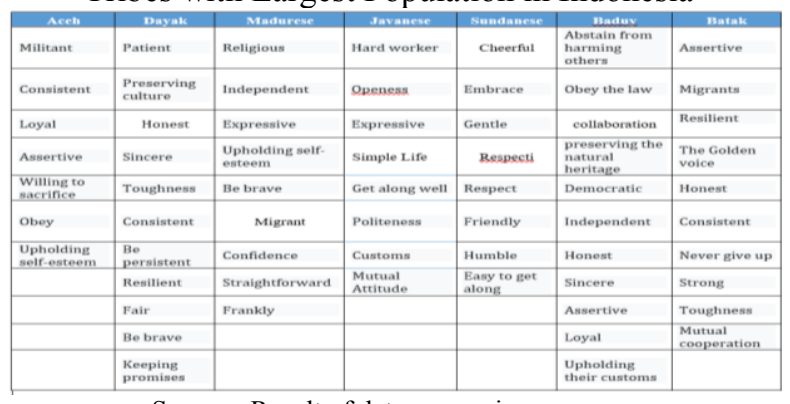

Source: Result of data processing

\begin{tabular}{|c|c|c|c|c|c|}
\hline Banjar & Minahasa & Betawi & Minangkabau & Malays & Bugis \\
\hline $\begin{array}{l}\text { Loyal } \\
\text { friend }\end{array}$ & Religious & Socialist & Nomads & $\begin{array}{l}\text { Hard } \\
\text { worker }\end{array}$ & Be brave \\
\hline $\begin{array}{l}\text { Like to } \\
\text { Trade }\end{array}$ & Discipline & $\begin{array}{l}\text { Cultural } \\
\text { practitioner }\end{array}$ & Simple & Polite & $\begin{array}{l}\text { Never give } \\
\text { up }\end{array}$ \\
\hline Religious & $\begin{array}{l}\text { Mutual } \\
\text { cooperation }\end{array}$ & Sincerely & Hard worker & $\begin{array}{l}\text { Mutual } \\
\text { help }\end{array}$ & Togetherness \\
\hline Empathy & Honest & $\begin{array}{l}\text { Easy to get } \\
\text { along }\end{array}$ & Straightforward & & \\
\hline Gentle & Fair & Polite & Egalitarian & & \\
\hline Loyal & Love to sing & & & & \\
\hline \multirow[t]{2}{*}{ Forgiving } & $\begin{array}{l}\text { Strong } \\
\text { brotherhood }\end{array}$ & & & & \\
\hline & $\begin{array}{l}\text { To be } \\
\text { responsible }\end{array}$ & & & & \\
\hline
\end{tabular}

Source: Result of data processing

There are at least ten generic superior traits identified from the superior characteristics of the studied tribes, including: Religious, Honest, Courageous, Sincere, Faithful, Migrant, Collaborative, Firm, Resilient, Friendly.

\subsection{National Values Identity and Excellence Ethnic Characters}

Pancasila as the basis of the philosophy of the state and the foundation of the Indonesian State, as well as the identity of the Indonesian nation [27] or the way of life of the Indonesian nation needs to be constantly applied in social interactions. Especially to the nation's future generations.

Figure 1 presents the relationship between the five principles of Pancasila and the values therein, with the superior characters of each ethnic group in Indonesia, which then identify their generic characters to become collective values integrated in the educational process.

The basis for implementing attitudes and actions related to the realization of the Pancasila principles is integrated in the learning of Pancasila Education courses and 3 national compulsory courses (Religion, Citizenship Education and Indonesian Language).

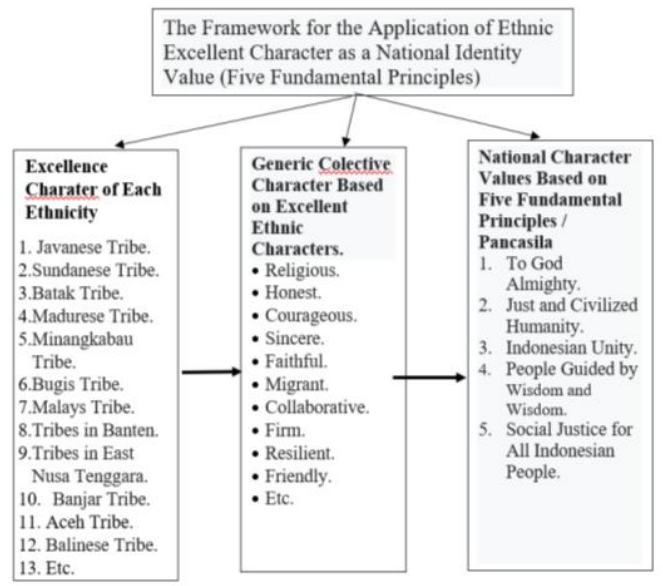

Figure 1 Framework of the Application of Ethnic Excellent Characters 
The relationship between the superior character of each tribe and the collective value of national identity and Pancasila is explained as follows. Every student needs to be aware of the superior character that is entrusted to him as a member of a certain tribe. Furthermore, through relationships between communities of different ethnicities, cooperation and mutual recognition can be built to find and agree on the existence of superior generic characters. At this stage, it is hoped that personal development will occur, namely Proud to be the Indonesian Nation. The implementation of Pancasila values in academic activities and extracurricular cooperation between students, especially those of different ethnic and religious backgrounds, is expected to form campus residents who have ten generic superior traits identified from the superior characteristics of the studied tribe, including: Religious, Honest, Courageous, Sincere, Faithful, Migrant, Collaborative, Firm, Resilient, Friendly.

The development of character education values based on ethnic superior character can be started from simple things that occur in an effective learning process. Furthermore, the teacher can describe the things shown by the cognitive, affective and behavior of students, both positive and negative, into constructs in accordance with the values of Pancasila [19].

\section{Conclusion}

Each tribe has a unique character which becomes the identity of the community. In a multi-ethnic and multicultural society like Indonesia, practical experience applying national identity values based on superior ethnic characteristics becomes essential. The study found ten generic characters - well manage excellence characters of a multicultural country very the potential to strengthen the values of the Indonesian national identity.

In addition, the implementation of superior character values sustainably and collectively will shape the personality and character of students who support the values of national identity as the embodiment of the Five Fundamental Principles, which is the basis of the State. At a minimum, it starts at an educational institution where students learn.

Constraints to the application of superior tribal character values in habituation in educational institutions include the process of cultivating values that may take a long time. Besides, the reluctance of students to get out of their "cocoons" and getting used to learning goodness from other tribes, changing habits that do not follow Pancasila values. Lack of exemplary from policymakers in educational institutions, and inadequate support for educational facilities/activities for the development of Religious, Honest, Courageous, Sincere, Faithful, Migrant, Collaborative, Firm, Resilient, Friendly collectively between cultures/ethnicities.

\section{ACKNOWLeDGMenT}

This research project is funded by the Ministry of Research, Technology and Higher Education Republic of Indonesia under the scheme of National innovation Research incentive year 2021.

\section{REFERENCES}

[1] Nevola Gaspare , Politics, Identity, Territory: The "Strength" and "Value" of Nation-State, the Weakness of Regional Challenge. 2011. Retrieved from https://core.ac.uk/download/pdf/150084107.pdf.

[2]. Ashmore R.D, Jussim L, and Wilder D (editors). Social Identity, Inter group Conflict, and Conflict Reduction. Oxford University Press. pp 74-75. 2001.

[3]. Tajfel H, Turner JC. The Social Identity Theory of Inter-group Behavior. Psychology of Intergroup Relations. 1986.

[4]. Oxford Dictionaries. Definition of National Identitiy in English. Retrieved on Jan 23, 2020.

[5]. Guibernau M. Anothony D. Smith. Nations and National Identity: a critical assessment. Nations and Nationalism. Vol.10 No.1-2, pp 125-141. 2004.

[6] Latif Yudi, "The Religiosity, Nationality, and Sociality of Pancasila: Toward Pancasila through Soekarno's Way", Studia Islamika Journal, 2018. Retrieved from http://journal.uinjkt.ac.id/index.php/studiaislamika/article/view/7502/4716

[7] Ministry of Research, Technology and Higher Education (MRTH), Pendidikan Pancasila untuk Perguruan Tinggi. 2016.

[8] Pitoyo. A.J and Hari Triwahyudi, Dinamika Perkembangan Etnis Di Indonesia Dalam Konteks Persatuan Negara. Jurnal Populasi, Vol 25 No.1, pp 64-81. 2017.

[9] CBS, “Data Suku di Indonesia.”, 2010, Download from https://www.bps.go.id/news/2015/11/18/127/menguli k-data-suku-di-indonesia.html

[10 ] C.Lasambouw, Ediana.S, Neneng.N. Keunggulan Etnik Di Indonesia Untuk Mendukung Penguatan Pendidikan Karakter: Suatu Studi Awal (The Advantages of Ethnics In Indonesia To Strengthen Character Education: An Initial Study). Proceeding Sentrinov Vol. 6 No. 2: Social and Humanities: pp 480-487, 2020.

[11] Vangelis Giannakakis, Studies in Philosophy and Education, Springer Nature B.V. 2019. Retrieved from https://doi.org/10.1007/s11217-019-09682-z

[12] Suyanto. Urgensi Pendidikan Karakter. 2011. Retrieved from http://www.mandikdasmen.depdiknas.go.id/web/pag es/urgensi.html.

[13] John Hutchinson. Ethnicity and Modern Nations. Ethnic and Racial Studies, Volume 23 Number 4. pp. 651-669 (C) 2000 Routledge Journals, Taylor \& 
Francis Ltd ISSN 0141-9870 print/ISSN 1466-4356 online. 2000.

[14] Asyanti S. Pendidikan Karakter Di Perguruan Tinggi : Sudah Terlambatkah?, Prosiding Seminar Nasional Psikologi Islami, Surakarta, hal. 284-291. 2012.

[15] Indonesian Online Dictionary 2012-2021, Meaning of Acculturation. Retrieved from https://kbbi.web.id/ acculturation.

[16] Azhar, I.N, The philosophy of the Nation's Leadership in Paribasan Jawa (Cultural Axiom That Has Started to Leave. Conference: Javanese Language Congress V, Vol. 1, Surabaya, DOI: 10.13140 / RG.2.1.5074.3125. 2011.

[17] Perceka, M.Z., Fahmi, I., Elisa Kurniadewi, E, Sundanese Student Ethnic Identity and Assertiveness. JPIB: Journal of Islamic Psychology and Culture, October 2019, Vol. 2 No.2, p. 63 - 76. 2019.

[18] Alfirdaus, L.K., Hiariej, E., and Adeney-Risakotta, F, Politics of ethnic relations: Matrilineality and ethnic Chinese minorities in Padang, West Sumatra. Journal of the Community Vol. 6 No.1, pp: 136-150. 2014.

[19] D. Budimansyah, N. Suharto, and I. Nurulpaik, Boosting Teacher's Perception and Deeds in
Indonesian Schools for the Character Education to Thrive. Proceeding Advances in Social Sciences, Education and Humanities Research, Vol 418, Atlantis Press. 2019.

[20] S. Bhattacharya, Ethnicity in Pakistan Conflict Impeding Nation Building, In book: Ethnicity, Nationalism and the State in South Asia. Publisher: Victorious Publishers. Download from https://www.researchgate.net/publication/353445898 Ethnicity in Pakistan_Conflict_Impeding_Nation Building/citations

[21] Egharevba Matthew E, Ethnic/Religious Insurgencies and Nation - Building in Nigeria. 2014. Download from https://www.researchgate.net/publication/268092458

[22] Hutchinson John, Ethnicity and modern nations, Taylor \& Francis, Volume 23, Issue 4, 2000. Download from https://doi.org/10.1080/01419870050033667 